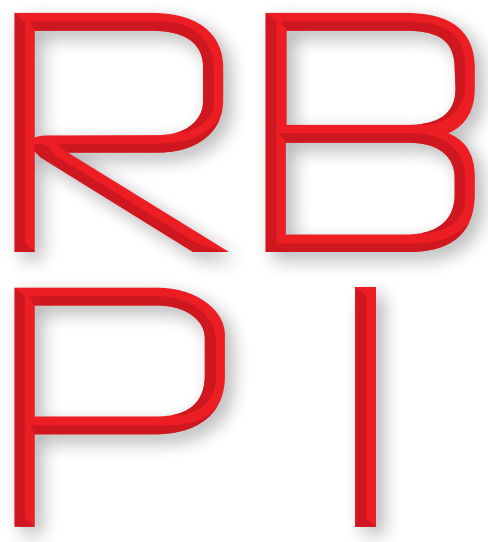

Revista Brasileira de Política Internacional ISSN 1983-3121

http://www.scielo.br/rbpi

\section{Juan Pablo Soriano ${ }^{1}$}

${ }^{1}$ Universitat Autònoma de Barcelona, Facultat de Cièncias Políticas y Sociología, Barcelona, Spain (juanpablo.soriano@ uab.cat)

iD ORCID ID:

orcid.org/0000-0003-4792-0042

Copyright:

- This is an open-access article distributed under the terms of a Creative Commons

Attribution License, which permits

unrestricted use, distribution, and reproduction in any medium, provided that the original author and source are credited.

- Este é um artigo publicado em acesso aberto e distribuído sob os termos da Licença de Atribuição Creative Commons, que permite uso irrestrito, distribuição e reprodução em qualquer meio, desde que o autor e a fonte originais sejam creditados.

\section{High expectations. Interregional agendas on global security challenges: East Asia, Europe and Latin America}

DOI: http://dx.doi.org/10.1590/0034-7329201900106
Received: December 10, 2018

Accepted: March 18, 2019

\title{
Introduction \\ Introduction
}

I

Abstract

Interregionalism has been increasingly used to advance cooperation on regional and global security challenges. This study examines three interregional dialogues comprising East Asia, Europe, and Latin America. Each interregional security agenda reflects specific concerns and different evolving paths. Insights from 'multilateral security governance' approaches can reinforce the analysis of how security agendas emerge and change, and how their related norms and practices evolve.

Keywords: ASEAN; CELAC; European Union; FEALAC; interregionalism; security governance.

T recent decades the international community has been challenged by an ever more globalized and interdependent world, which generated serious challenges and threats that cannot be effectively dealt with by unilateral action. Although the impact of these challenges and threats on countries and regions diverge, these complex issues have the potential to multiply instability and conflict, and have disastrous humanitarian consequences (Heine and Thakur 2011; Ruzza et al. 2015). States and international organizations are struggling to cope with a wide range of security challenges, which include both the traditional range of conventional, state-centered military concerns, as well as 'non-traditional security' (NTS) issues. These NTS matters are thought to traverse national borders or operate beyond the scope of conventional state action, and include matters such as terrorism, environmental degradation and climate change, infectious disease, 
transnational crime, and illegal migration, among others (Hameiri and Jones 2013). NTS issues, which are transboundary in nature, require comprehensive responses (Caballero-Anthony 2016), and seem to also require new forms of interregional governance.

In this context, during the last two decades we have seen interregional dialogue forums becoming an important systemic international phenomenon. These multilateral forums include a diversity of bilateral, regional and multilateral, formal and informal structures, "involving regions and states as well as geographic regions and constructed regions" (Baert et al. 2014, 172). These multi-regional forums have received substantial scholarly attention in recent years (Breslin and Croft 2013; Kacowicz and Press-Barnathan 2016; Ceccorulli and Lucarelli 2013; Santini et al. 2014), and have attracted the attention of policymakers and security practitioners. An example of the latter was the open debate held by the United Nations Security Council (UNSC) in December 2017, on "Addressing complex contemporary challenges to international peace and security" (UNSC 2017). During that debate numerous pleas were made to rethink the approaches used to address increasingly complex and interconnected global security challenges. Issues identified as challenges to peace and security included a wide number of both traditional and NTS threats and challenges. The results of interregional efforts in coping with increasingly complex security issues are still below the expectations of policymakers and ordinary citizens all over the world. Nonetheless, even if an important part of interregional cooperation is still rhetorical or symbolic, it could be a stepping-stone towards stronger multilateral security cooperation (Rüland et al. 2006).

By analyzing three interregional dialogues, which comprise seventy-seven countries from East Asia, Europe, and Latin America and the Caribbean (LAC), this article explores a set of empirical matters, and proposes that the insights provided by studies on 'security governance' can help understand interregional security cooperation. The empirical research is aimed at answering three interrelated matters: how do these interregional dialogues describe the international security environment of the last two decades? What role do these interregional forums assign to multilateral cooperation in confronting global security challenges and threats? And which has been the evolution of the security agendas of different interregional forums in the last two decades? On the other hand, multilateral security governance can help us suggest possible lines to advance the comparative study of how interregionalism is being used as a vehicle to define and address global security challenges. Important as they are, at this stage the objective of this research is not to assess whether the bi-regional security agendas have created specific norms or policy practices, interregional programs or budgeting lines; those matters will be addressed in future studies.

The three interregional forums examined in this study are: the dialogue between the Association of Southeast Asian Nations (ASEAN) and the European Union (EU), the dialogue between the EU and the countries of Latin America and the Caribbean, and the Forum for East Asia-Latin America Cooperation (FEALAC; or FOCALAE in Spanish). We analyze thirty-two summit declarations, statements of ministerial meetings and joint action plans from these dialogues from 1997 to 2018. 
Content analysis has been used to categorize and quantify the data obtained from the documents, and to observe key trends in the three interregional security agendas.

Such analysis is relevant for several reasons. First, most of the empirical studies on interregional relations result from the analysis of triadic relations between North America, the EU and East Asia, and a substantial number of studies are related to Asia-Europe relations (Rüland 2014, 18). Besides providing additional empirical information from the ASEAN-EU and EU-LAC security agendas, this study offers new empirical data from the interaction between East Asia and LAC (see also: Abad 2010; Low 2006; Tsardanidis 2010; Engel et al. 2016). Second, interregionalism may not be the dominant trend in world politics; nevertheless, it is important to continue studying its possible 'systemic repercussions' and potential implications for global security governance (Baert et al. 2014; Song 2007). Regional and interregional cooperation may influence the shared knowledge and understanding of different stakeholders on the nature and extent of global security challenges (Betts 2011, 42). Third, by analyzing these three multilateral security agendas' transformation of over time, their areas of convergence and divergence, as well as continuity and change, can be identified and further studied.

The regional dialogues analyzed in this article are different in their formal and informal mechanisms, the scope of policy issues they cover, and the norms and practices they share (Börzel and Risse 2016; Rüland 2014). In these three regions, there are different approaches to regional integration which generate diverse institutional practices, and different positions towards the ideas of regional identity/identities. Although these matters hinder the possibility to affirm these interregional forums' collective voice at the global level, their continuous existence has the potential to contribute to tackling some of the most pressing issues of the current global security agenda.

The rest of this article is organized as follows. First, a brief review of recent literature on interregionalism and security governance is offered. Second, a general overview of the three interregional dialogue forums is introduced. Third, the methodology of content analysis used in this article is explained, and the quantitative results of the analysis are presented. Fourth, the assessment each dialogue has made of the regional and global security environments is discussed. Fifth, an initial exploratory analysis of the evolution of the three interregional security agendas is made. Finally, some general conclusions are provided.

\section{Interregionalism studies and security governance}

Since the end of the 1990s, the proliferation of interregional dialogue forums had become an important feature of the international arena, both from an academic and a policy perspective. From the academic point of view, the literature studying the "genesis, formats, functions, performance and prospects" of interregionalism flourished (Rüland 2014, 15). According to Rüland, an important part of this literature had "the optimistic belief that interregional relations have the potential of becoming significant building blocks of an emerging, increasingly 
vertically and horizontally differentiated, multilayered global governance architecture" (Ibid.). The evolution of international politics during the first decade of the twenty first century, however, lowers expectations of the positive, transformative power of interregional dialogues and forums. For some authors, "the expectation that interregionalism could evolve into something approximating collective identity-building" appeared too ambitious, particularly given "inherent cultural barriers in cross-regional cooperation that stem from the very defining of regions as cultural or identitarian blocs" (Santini et al. 2014, 78). In this sense, some argued that it was more realistic "to expect interregionalism to result in occurrence on a limited set of values or norms - such as the management of illegal immigration and organized crime - rather than in generating new political communities" (Ibid.).

These adverse outcomes helped generate the general impression among International Relations scholars that the research agenda on interregionalism had "reached conceptual and empirical limits," and had stopped the understanding of global governance and the policy dynamics related with multilateralism (Rüland 2014, 15). Different authors, however, have indicated that there is still space to innovate on interregionalism studies (Rüland 2014; Santini et al. 2014; Börzel \& Risse 2016; Engel et al. 2016; Koschut 2018; Rubiolo 2018, among others). Some areas prone to further innovation would include: efforts to build a broader consensus on what defines interregionalism; assessment of 'actorness' characteristics of regional organizations in interregional dialogues ('balancing', 'institution-building', 'agenda-setting' of new themes and agendas, and 'collective identity-building', among others); empirical studies on interregional relations, which include South-South interregionalism; further analysis of the democratic deficit of interregional dialogue forums; identification of opportunities and constraints that interregional interactions create for different actors in different issue areas; broadening of the study of interregional relations ideational dimension, and specifically the role of interregionalism in the diffusion and dispute of norms; recognition of the functions which interregionalism could perform, or is already performing, in the creation of a global governance architecture; and, evaluation of the prospects for interregional dialogues in an international context characterized by growing multipolarity, a return to geopolitics, and increasing nationalism and protectionism.

Concerning the broad area of security matters, some authors argue that the concept of 'security governance' appears to be "particularly promising for analysing the role of interregionalism in reframing security cooperation" (Santini et al. 2014, 83. On security governance see also: Krahmann 2005; Caparini 2006; Kirchner and Sperling 2007; Britz and Ojanen 2009; Sperling 2009; Christou et al. 2010; Lucarelli et al. 2013; Santini, et al. 2014; Koschut 2018). Security governance "involves, actors at all levels from national, through the interregional and all the way up to the global levels," providing "a conceptual framework for locating processes that are unlikely to replace the identity-building processes of regionalism but that could supplement them by creating a degree of norm convergence across regions" (Ibid., 83-84, emphasis in the original). Regarding policy implications, security governance encompasses a varied type of actions, by public 
and private actors, "which include defining the nature and sources of security problems, devising plans and policies to ameliorate them, engaging in the actual management of these issues, and auditing the performance of security practitioners" (Hameri and Lee 2013, 464). In this regard, the idea of multilevel and multilateral security governance implies a system "in which states are still, the main actors but other actors -global, regional, local and transnational-play a key role as well” (Santini et al. 2014, 83).

Therefore, a 'security governance' approach to interregional relations could allow: assessments of the impact of interregional security cooperation on "norm convergence on security matters across regions" (Santini et al. 2014, 84); analyses on how the development of interregional security agendas could generate a 'division of labour' in global governance (Ibid.); and, studies on how the proliferation of different levels of security governance (interregional, trans-regional, regional, sub-regional, national, etc.), and their associated norms and practices (Wiener 2014, 2018; Acharya 2018), could improve or diminish the possibilities of improving coordination among different stakeholders, in order to tackle different issues on the global security agenda.

\section{Overview of the interregional dialogue forums}

The ASEAN-EU dialogue, although formalized in 1977, dates back to 1972. This bi-regional dialogue recognizes a shared commitment to regional integration as a means to promote regional stability, improve prosperity, and jointly address global issues. Currently, ASEAN-EU relations are guided by the Nuremberg Declaration on Enhanced Partnership, adopted in 2007. It establishes a long-term vision and the commitment to jointly work on achieving common goals and objectives. With the adoption of the ASEAN Charter in 2008, both organizations initiated formal diplomatic relations in 2009, and in 2015 the EU established a Diplomatic Mission to ASEAN. In 2018, the ASEAN-EU dialogue encompassed thirty-eight states: Austria, Belgium, Brunei Darussalam, Bulgaria, Cambodia, Croatia, Cyprus, Czech Republic, Denmark, Estonia, Finland, France, Germany, Greece, Hungary, Indonesia, Ireland, Italy, Laos, Latvia, Lithuania, Luxembourg, Malaysia, Malta, Myanmar, Netherlands, Philippines, Poland, Portugal, Romania, Singapore, Slovakia, Slovenia, Spain, Sweden, Thailand, United Kingdom, and Vietnam.

The ASEAN-EU relationship has been the object of numerous works in the last four decades. In fact, it has been at the center of the study of interregionalism (Hänggi 2006; Reiterer 2006; Storz and Rüland 2008; Rees 2010; Baert et al. 2014; Meisser 2015). Some of these analyses have highlighted how the EU has attempted to increase its presence in the world by supporting regional integration efforts in South East Asia, by increasing its political and economic relations with the region, and by trying to balance the enormous influence of the United States and China in that area of the world. Also, EU-ASEAN relations have been considered a promising case for the EU to export its model of multi-level governance, enhance its 'actorness' and influence at the global level (Doidge 2014). Although this interregional 
relationship has evolved into a deeper and multifaceted one, uncertainty about its future has grown in recent years. On the one hand, questions arise regarding the political and economic resources which the EU can offer to support processes of integration in other regions, after years of economic crisis, increasing political polarization and uncertainties about the future path of European integration. On the other, ASEAN is progressively confirming its role as a relevant regional organization while "defending the political, economic and institutional norms which it adheres, and which do not always align with those of the EU, or those promoted by the EU to ASEAN" (Allison 2015, 3).

The long-standing relation between the EU and LAC combines different levels of interaction - regional, sub-regional and bilateral -, and comprises a wide range of issue areas. This relationship became a 'strategic partnership' in 1999, when the first bi-regional summit was held in Brazil. In 2011, the Community of Latin American and Caribbean States (CELAC) was created, conforming a regional mechanism for political coordination which brings together thirty-three countries of LAC. Since 2013, CELAC is the EU's official counterpart for bi-regional summits. In this article, 'EU-LAC' refers to the bi-regional dialogue between 1999 and 2013, 'EU-CELAC' for the following years, and 'EU-LAC/EU-CELAC' refers to both periods. In 2018, the EU-CELAC interregional dialogue included sixty-one states: Antigua and Barbuda, Argentina, Austria, Bahamas, Barbados, Belgium, Belize, Bolivia, Brazil, Bulgaria, Chile, Colombia, Costa Rica, Croatia, Cuba, Cyprus, Czech Republic, Denmark, Dominica, Dominican Republic, Ecuador, El Salvador, Estonia, Finland, France, Germany, Greece, Grenada, Guatemala, Guyana, Haiti, Honduras, Hungary, Ireland, Italy, Jamaica, Latvia, Lithuania, Luxembourg, Malta, Mexico, Netherlands, Nicaragua, Panama, Paraguay, Peru, Poland, Portugal, Romania, Saint Kitts and Nevis, Saint Lucia, St. Vincent and the Grenadines, Slovakia, Slovenia, Spain, Suriname, Sweden, Trinidad and Tobago, United Kingdom, Uruguay and Venezuela.

In recent years, different analyses have indicated a certain sense of fatigue in the EU-CELAC relationship, and therefore the need to renew or relaunch it, taking into account subregional schemes, regional diversities, existing asymmetries, and the tensions and fragmentation that this multilevel interregionalism generates (Domínguez 2015; Ayuso 2015; Sanahuja 2015). Regarding the specific area of cooperation on security matters, in the last two decades, numerous political, operational and technical exchanges and mechanisms have been created to promote and coordinate it; and different studies have been produced to analyze the formal and informal instruments this cooperation has adopted. For example, some of these works have questioned the viability of EU security cooperation initiatives fitting together in a coherent and comprehensive policy towards LAC, and have underlined the need to assess whether EU initiatives are producing the expected positive outcomes (Stambøl 2016b). Other studies have questioned the supposed effectiveness of the EU-LAC approaches promoted to fight transnational crime, and specifically drug trafficking (Selleslaghs 2016). Some investigations have emphasized the regional imbalance of power relations, focusing on how the EU is externalizing its fight against drug trafficking and terrorism to third countries 
in Latin America and West Africa (Stambøl 2016a). Finally, other works have examined the obstacles for the advance of the bi-regional security agenda, particularly its traditional hard-military aspects (Malamud and Seabra 2015).

FEALAC is an association created in 2001 as an official and regular dialogue forum between countries from East Asia and LAC, although its origins can be traced back to 1999, when the East Asia-Latin America Forum of Senior Officials' Meeting was held in Singapore. In January 2004, during the second Meeting of Ministers of Foreign Affairs, the Manila Action Plan was adopted, proposing a path to foster mutual understanding and cooperation on different issue areas, but especially to explore and exploit their shared economic potential. In 2018, FEALAC included thirty-six states: Argentina, Australia, Bolivia, Brazil, Brunei Darussalam, Cambodia, Chile, China, Colombia, Costa Rica, Cuba, Dominican Republic, Ecuador, El Salvador, Guatemala, Honduras, Indonesia, Japan, Laos, Malaysia, Mexico, Mongolia, Myanmar, New Zeeland, Nicaragua, Panama, Paraguay, Peru, Philippines, Korea, Singapore, Suriname, Thailand, Uruguay, Venezuela, and Vietnam.

Besides enhancing cooperation on economic and political relations, this forum can be viewed as "the result of a diversification strategy" aimed at strengthening the position of its participants in North-South dialogues (Tsardanidis 2010, 231), and as a transregional network created to balance its other members' regional relations (Doidge 2014). This forum is the only bi-regional dialogue and cooperation space that goes beyond the concept of the Pacific, including countries from the Atlantic and Caribbean basins. In fact, for many countries in Latin America, it is the only forum available for cooperation with East Asia as a region (CEPAL 2013). However, several factors have created difficulties for advancing collective goals, cohesion, 'actorness' and a relevant impact for FEALAC in the international system: its non-binding nature, the absence of an "effective mechanism for intra-group cooperation," limited financial resources, an emphasis on "regulative principles as non-interference," and the fact that neither East Asia nor LAC are constituted as actors within the forum (Doidge 2014, 50-51; Rubiolo 2018).

\section{Methodology and categorization of interregional security agendas}

The content analysis practiced in this article follows the methodology proposed by Bryman (2012) and Elo et al. (2014), aiming to generate quantitative accounts of the data obtained in the analysis of key documents of the selected case studies. Content analysis is a transparent research method, and it allows "certain amount of longitudinal analysis with relative ease" (Bryman 2012, 304). This article uses an inductive approach to create categories from raw data "without a theory-based categorization matrix" (Elo et al. 2014). It examines the stated content of the documents: the information that can be observed in the surface structure of the texts: its 'manifest content.' It is not concerned with the deep structure of the texts, what was intended to be said: its 'latent content' (Bryman 2012, 290). 
Content analysis is said to be a research tool that faces difficulties determining answers to 'why?' type questions. In this sense, researchers might suggest explanations for 'interesting findings,' however, these could be no more than speculations, "more or less theoretically informed" (Bryman 2012, 306). Also, content analytic studies have been accused of being 'atheoretical,' since the emphasis on measurement can easily and inadvertently result in highlighting "what is measurable rather on what is theoretically significant or important" (Bryman 2012, 307). Aware of these limitations, this study considers content analysis to be adequate for the proposed mapping exercise and preliminary comparative analysis.

The data was obtained by examining thirty-two documents from all three aforementioned interregional forums, from 1997 to 2018, produced in bi-regional agreements or negotiations. Fourteen documents, produced between 1997 and 2017, were reviewed from the ASEAN-EU dialogue; twelve documents, produced between 1999 and 2018, from the EU-LAC/CELAC dialogue; and seven sources, produced between 2004 and 2017, for the FEALAC dialogue. There are clearly less documents from the FEALAC dialogue, since the first statement of its bi-annual ministerial meetings including a specific agenda on global challenges dates from 2004 .

Before presenting the results, a brief explanation of the procedure followed to assign the raw information from the documents to the categories is needed. The first step was to identify the key documents guiding the bi-regional dialogues in the last two decades, such as: bi-regional political declarations, bi-regional action plans, or statements of bi-regional ministerial meetings. These materials were retrieved from the webpages of the European External Action Service (European Union 2016), ASEAN (s. a.), FEALAC (s. a.), and the Digital Library of the EU-LAC (1999a). With the information from these materials, a first matrix was created, containing: the document's date, the type of document (joint declaration/joint statement/action plan), its institutional authors, title, and the URL from where the document was retrieved. Once chronologically ordered, they were numbered.

The following step was to identify sections in each document referencing two sets of matters: the assessment of the global security environment, and the issues considered regional or global security challenges or threats. As indicators of subject matters, we have searched for specific key words, such as security, threats, risks and challenges. In a second search, more specific words and concepts were identified: complex/complexity, global threats/challenges, interconnected threats/challenges, military issues, multidimensional, non-military issues, traditional and non-traditional security issues, and transnational issues/threats. For this process we have used the advance search tool from a PDF viewer program (in this case, Adobe Acrobat Reader).

After the results were obtained, the next step was to develop a preliminary pilot list of issues considered in the documents as regional and global challenges or threats; this first list included thirty-eight categories organized and simplified in a following step. The result was a list of twenty-five different categories to code the documents' information.

Two caveats should be made before introducing the categories. First, following Bryman's advice to identify potential pitfalls in devising categories, we have tried to avoid conceptual or 
empirical overlaps between the categories which could generate broad misunderstandings on how to interpret the meaning of each dimension, and what factors to consider when coding each category (Bryman 2012,303). Nonetheless, some categories in this study subsume an extremely large number of items because not all documents break down these dimensions in different activities or phenomena. This is the case for 'climate change' and 'transnational organized crime.' In the case of 'climate change,' the reviewed materials occasionally presented it as a threat, or as a phenomenon that has negative consequences; in certain documents there are no concrete examples of its adverse consequences. In others, 'natural disasters' are presented as a direct consequence of 'climate change.' In most occasions, however, 'climate change' is presented as a global challenge. Therefore, this study differentiates between 'climate change' and 'natural disasters' to identify the specific ways in which the documents reflect the negative implications of these challenges. Regarding 'transnational organized crime,' some documents present it as a broad phenomenon, and others break down its different manifestations and related criminal activities. In order to identify specific concerns in each agenda, this article includes 'transnational crime' as a broad category, and uses other specific categories to identify its different manifestations.

Second, there are several issues which other policy documents usually identified as 'global security challenges,' but they were not included because they were not considered in any of the thirty-two documents reviewed. Those matters include: ethnic conflict, foreign fighters, hybrid threats, massive and uncontrolled migration flows, violence against vulnerable minorities, and transnational gangs, among others (for an assessment of these matters see OECD 2016; UNSC 2017).

\title{
Table 1. Categories used to code the interregional dialogues' documents. *
}

Climate change
Corruption
Cultural property trafficking
Cyberspace challenges
Drug trafficking
Human smuggling
Human trafficking
Illegal fishing
Illicit arms production and trafficking
Illegal trade in mining products
Infectious diseases and pandemics
Maritime security and safety
Money laundering

\author{
Natural disasters \\ Proliferation of weapons of mass destruction (WMD) \\ Racism, xenophobia and intolerance \\ Sea piracy \\ Smuggling of goods \\ Terrorism \\ Trafficking in forest products \\ Trafficking in pharmaceutical products \\ Transnational crime \\ Violence against women and girls \\ Violent extremism \\ Wildlife crimes
}

* The author can provide more information on how each category was created

After coding the information with the previous categories, we have elaborated a Table (Figure 1), and a Chart (Figure 2) presenting the three interregional agendas' evolution on regional and global challenges. 
Figure 1. Chronological evolution of interregional security agendas in the ASEAN-EU, EU-LAC/ EU-CELAC, and FEALAC dialogues (1997-2018).

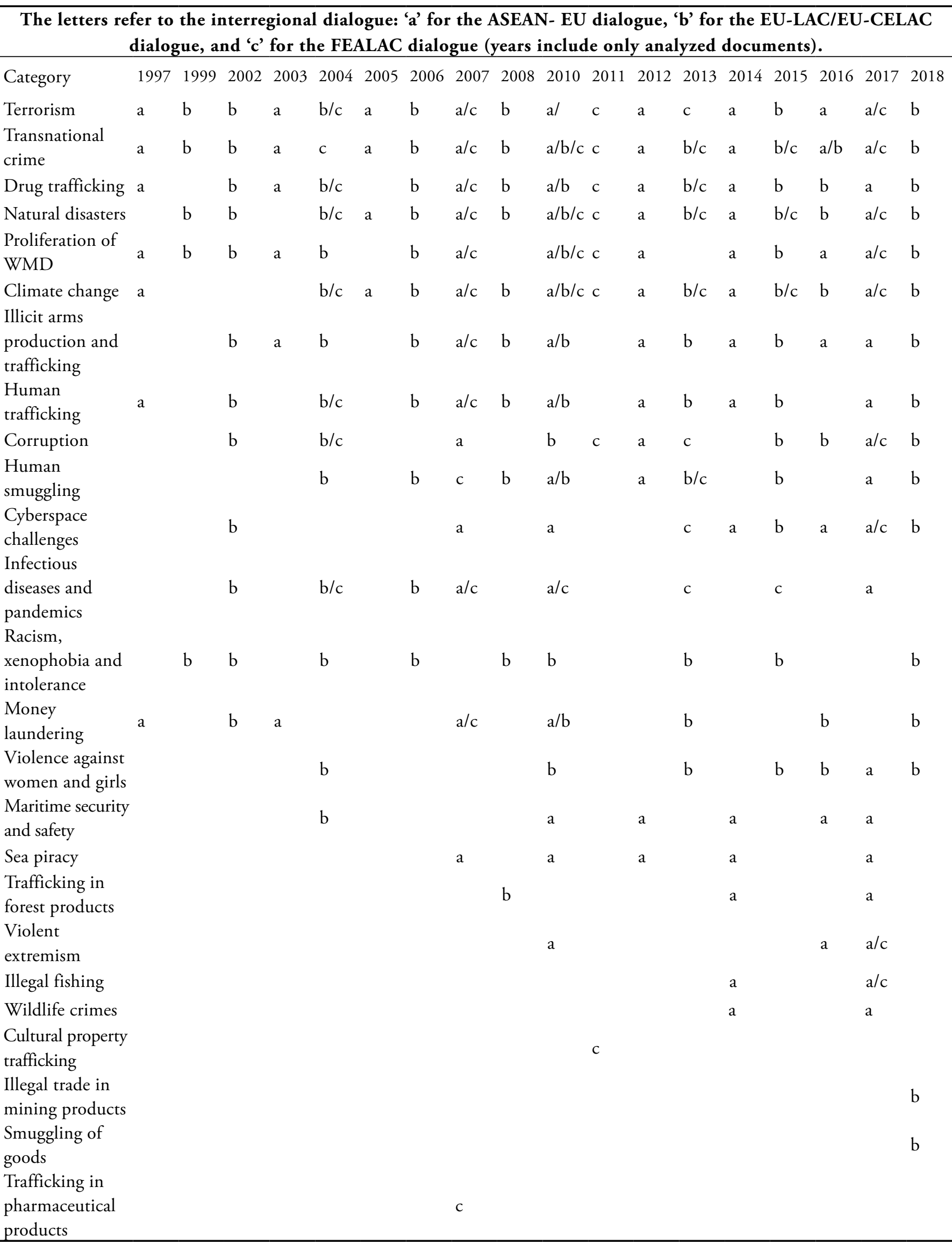

Source: own elaboration. 
Figure 2. Chronological evolution of the number of items included as bi-regional and global challenges with a security component in the ASEAN-EU dialogue, the EU-LAC/EU-CELAC dialogue, and the FEALAC dialogue (1997-2018)

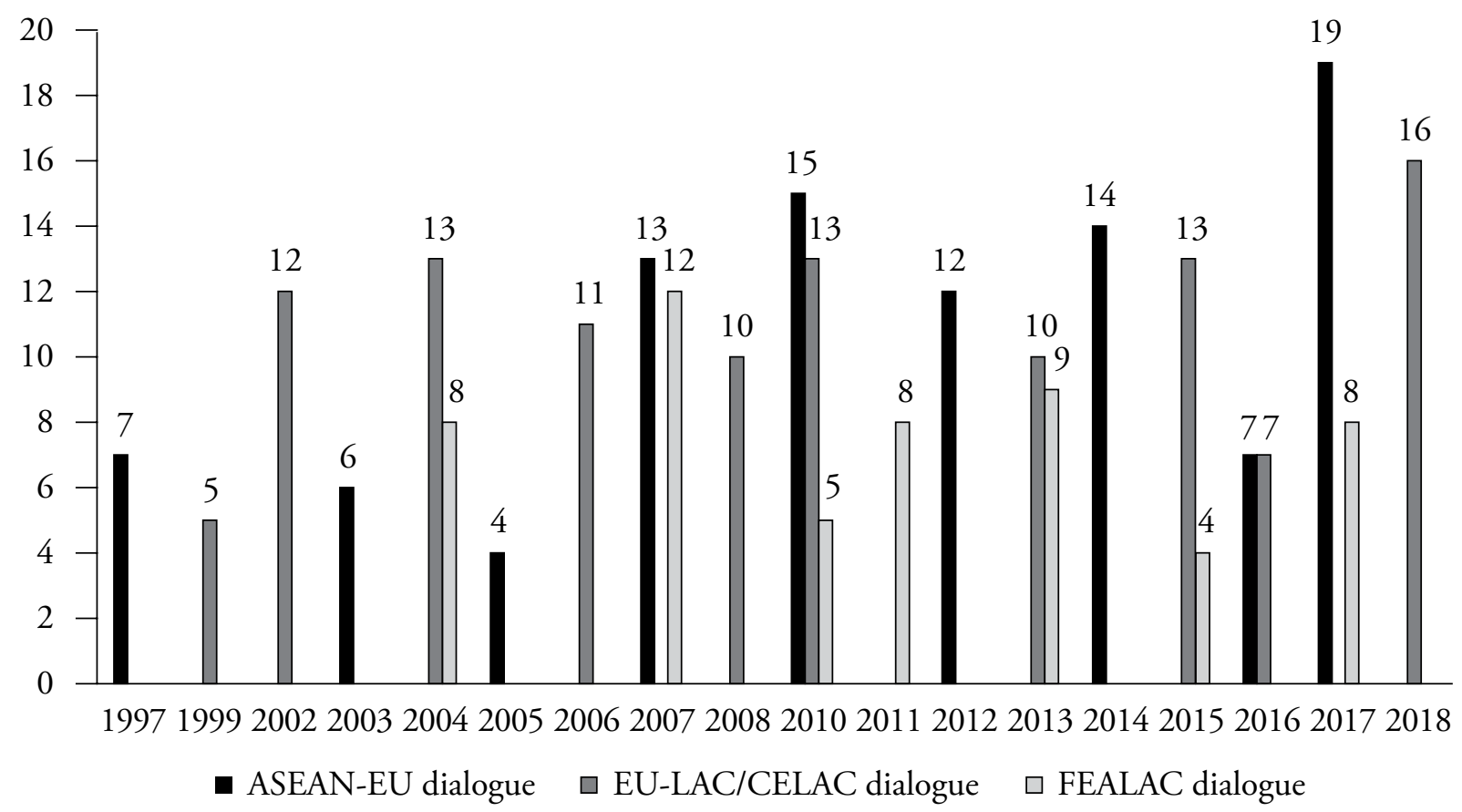

Source: own elaboration

\section{Assessment of regional and global security environments}

This section examines the assessment made by interregional forums of the international security environment in the last two decades, as well as the roles they assign multilateral cooperation to confront global challenges and threats. The analysis is organized in four different periods: the late 1990s, first half of the 2000s, second half of the 2000s, and the 2010s.

\section{Late 1990s: positive and negative effects of globalization}

By the late 1990s, the ASEAN-EU and EU-LAC dialogues were favoring the development of closer international cooperation to respond to the new and serious challenges emerging in an increasingly globalized world. Documents from this period show a consensus around two arguments: that the complex phenomenon of globalization brought new challenges and accelerated others, and that, in order to tackle these challenges, more multilateral cooperation was needed (ASEAN-EU 1997; EU-LAC 1999b). During this period, the issues identified as threats or challenges included matters that would become permanent components of both interregional dialogues: terrorism, transnational crime - emphasis on drug trafficking-, proliferation of WMD, the negative effects of environmental degradation, and natural disasters (see Figures 1 and 2). At that moment, the FEALAC dialogue was not active. It is important to highlight that during this period the EU-LAC agenda introduced the need to fight racism, xenophobia and intolerance (EU-LAC 1999b), and 
this item has been maintained ever since. Nevertheless, these matters have not been specifically mentioned in any of the documents of the other two bi-regional dialogues.

\section{First half of the 2000s: global challenges of the new millennium}

At the beginning of the 2000s, these interregional forums shared the view that the challenges generated by an increasingly interdependent world required more regional and global cooperation (ASEAN-EU 2003a; 2003b; 2005; EU-LAC 2002; 2004; FEALAC 2004). In this period, the number of issues considered regional and global challenges in the ASEAN-EU agenda remained quite the same as in the previous period -between five and six different categories (ASEAN-EU 2003a, 2003b, 2005)-, and the category of natural disasters was introduced (Ibid. 2005) (see Figures 1 and 2).

In the case of the EU-LAC dialogue, the issues in the bi-regional agenda increased, and their description became more specific. For example, the documents became more precise regarding the different activities related to transnational crime - trafficking in drugs, people and arms, and human smuggling - ; and new issues were introduced, such as corruption, cyberspace challenges, infectious diseases and pandemics (EU-LAC 2002). It is during this period that VAW was included in the EU-LAC dialogue (EU-LAC 2004), although it did not appear again in their bi-regional statements until the end of the decade (EU-LAC 2010). In the case of the FEALAC dialogue, their first joint statement including a common agenda on global challenges was presented in 2004. In addition to terrorism and transnational crime, their agenda included corruption, human trafficking, infectious diseases and pandemics, natural disasters, and the negative consequences of climate change (FEALAC 2004).

\section{Second half of the 2000s: transnational and interconnected complex challenges}

Besides recognizing the need for broader and deeper cooperation to address regional and global challenges, another argument was shared by these interregional dialogues: that the roots and effects of regional and global challenges were multidimensional, interconnected and growing (ASEAN-EU 2007b; EU-LAC 2008; FEALAC 2007). FEALAC declarations, for example, showed concern with "the continuous growth of challenges" in a "complex and multifaceted world order"; and stated that "no single country, or group of countries, would be able to tackle alone the interconnected threats facing the international community" (FEALAC 2007). The ASEAN-EU dialogue specified that security should be understood from a multidimensional point of view, including its political, human, social and economic dimensions (ASEAN-EU $2007 \mathrm{a} ; 2007 \mathrm{~b} ; 2007 \mathrm{c}$ ).

During the second half of the 2000s, the ASEAN-EU agenda showed a very significant increase in the number of issues considered regional and global challenges (see Figures 1 and 2). Their agenda was broadened to include new categories, such as cyberspace challenges, infectious 
diseases and pandemics, and sea piracy (ASEAN-EU 2007a; 2007b; 2007c; 2010). It should be highlighted that during this period the concept of non-traditional security (NTS) was introduced in the security lexicon of the ASEAN-EU dialogue (ASEAN-EU 2003b). This concept, broadly used in the ASEAN framework since the early 2000s, can also be found in the official deliberations of regional institutions such as ASEAN, the ASEAN regional forum, the ASEAN dialogue with China, Japan and South Korea (ASEAN plus three), among others. Civil society organizations have also promoted NTS issues in their advocacy work, and the concept has become part of the security lexicon in Asia and beyond (Caballero-Anthony 2016).

The concept of NTS issues "has found traction in Asia's policy community." This is reflected in the official deliberations of regional institutions such as ASEAN, the ASEAN regional forum, the ASEAN dialogue with China, Japan and South Korea (ASEAN plus three), among others. Civil society groups across the region have also identified with and promoted NTS issues in their advocate work. More significantly, NTS has become "part of the security lexicon not only within Asia but also beyond the region" (Ibid. 7). In the ASEAN-EU dialogue, the concept of NTS has been progressively included in several documents, in order to enhance political and security dialogues (ASEAN-EU 2007c; 2010; 2016; 2017b). A thought-provoking fact, beyond the scope of this article, is that the concept of NTS has not been included in the security lexicon of the EU-LAC dialogue, neither in the FEALAC dialogue - in which many members of ASEAN also take part.

Regarding the number of categories included in the EU-LAC security agenda, it decreased from thirteen different issues in 2004 to ten in 2008 (EU-LAC, 2005, 2006, 2008); meanwhile, the FEALAC agenda experienced a considerable expansion, reaching up to twelve different categories including human smuggling and money laundering as new issues. The FEALAC dialogue, however, does not mention cyberspace challenges, maritime issues or VAW (FEALAC 2007).

\section{The 2010s: protect and promote multilateralism}

Between 2010 and 2018, the international context becomes more complex and challenging. This is reflected in the constant expansion of the three agendas - more clearly in the ASEAN-EU and EU-CELAC agendas (see Figure 2). A new argument, however, is presented: transnational security challenges have become a threat not only to the state's and citizen's security, but also to the global multilateral framework (FEALAC 2015; 2017). In this setting, rule-based approaches to promote security and prosperity for citizens are said to be essential; as well as effective and inclusive global governance mechanisms to cope with the multifaceted and problematic international environment. During this period, the ASEAN-EU dialogue diagnosis is that the 'growing common challenges and threats' emerged both from within and without their regions, and the dialogue restates its commitment to promote rule-based approaches to address global matters effectively and multilaterally (ASEAN-EU 2012a; 2012b; 2014: 2016; 2017a). 
The EU-CELAC dialogue also upheld its willingness to strengthen cooperation in order to face global challenges, and emphasizes the need to promote multilateralism, inclusive global governance and respect for international law (EU-CELAC 2015; 2016a; 2018). In regards to its security lexicon, during the 2010s, the concept of 'citizen security' was introduced in bi-regional plans and actions, both as a concept to characterize the relation between states and their citizens on security policies, and as an area for bi-regional cooperation. The concept was introduced in LAC in 2009 to differentiate the nature of security in democracy against security in authoritarian regimes (IACHR 2009). In the case of the bi-regional dialogue, in 2014 the EU established a Strategy on Citizen Security in Central America and the Caribbean, and in 2015 a chapter on 'citizen security' was introduced into the EU-CELAC dialogue. This concept, however, has still not been introduced in the lexicon of the FEALAC dialogue.

\section{Evolving interregional security agendas}

Regarding the evolution of these interregional security agendas, there are different trajectories in the number and type of issues which have been included - and excluded - in the last two decades (see Figures 1 and 2). The clearest feature is the progressive and fast expansion of the ASEAN-EU agenda; in 2017 the number of issues included was the largest of all three dialogues between 1997 and 2018 (ASEAN-EU 2017b). This does not necessarily mean that governments from ASEAN and the EU are ready to commit substantial resources, during an extended period of time, to deal with this large agenda. To determine whether this broader agenda is more than a 'shopping list' approach without practical consequences, further analysis of bi-regional programs and actions would be necessary (given space constraints, the present paper is not the appropriate space to do so).

Another element is a relatively constant number of issues in the EU-LAC/EU-CELAC, until the most recent evidence, which clearly shows an increase. In the 2002-2015 period, this agenda included between ten and thirteen categories, seven in 2016, and sixteen in 2018 (UE-LAC 2002; EU-CELAC 2016a; 2016b; 2018). The situation in 2016 may reflect an impasse between the risk of being trapped in bi-regional cooperation strategies from the past, and setting the conditions for a paradigm change that could open new forms of cooperation to deal more effectively with regional and global challenges (Ayuso and Gratius 2016).

The FEALAC agenda shows an irregular broadening and limiting path. In 2007 this agenda included twelve categories, and in 2015, only four; in 2017, the year of the last observation, it included eight categories, as in 2004 (FEALAC 2004; 2007; 2010; 2011; 2013; 2015; 2017). This could be related to problems in reaching consensus on a broader agenda, in identifying common security concerns, or even difficulties defining the whole purpose of the interregional dialogue. Alternatively, it could indicate an agreement to focus on specific issues, increase effectiveness and avoid the dispersion of limited political, economic and institutional 
resources. However, a limited agenda would not necessarily imply effective actions to respond to common challenges.

When it comes to items being included in the bi-regional agendas, they converge around seven key regional and global challenges: terrorism, transnational crime, drug trafficking, natural disasters, climate change, human trafficking, and illicit arms production and trafficking (see Figure 1). It would not be wise, however, to develop high expectations on the premise that the convergence of interregional security agendas could easily translate into common, coordinated and effective actions, since each of these agendas reflects specific regional realities and concerns that may distract resources of all kinds from a common global security agenda (Baert et al. 2014).

In the ASEAN-EU dialogue, four different blocs of key concerns can be observed. At the top, there are terrorism, transnational crime and proliferation of WMD. In a second bloc, climate change, illicit arms production and trafficking, drug trafficking, human trafficking and natural disasters. In a third, cyberspace challenges, sea piracy and maritime security and safety. Regarding the EU-LAC/CELAC dialogue, the most relevant concerns can be divided into two blocs. At the top: natural disasters, drug trafficking, transnational crime, racism, xenophobia and intolerance, climate change, human trafficking, illicit arms production and trafficking, and terrorism. In a second bloc: human smuggling, proliferation of WMD, corruption and violence against women. At FEALAC, the most relevant issues can be separated into three blocs: at the top, climate change, natural disasters, and transnational organized crime; followed by terrorism, infectious diseases, corruption and drug trafficking in a second bloc.

Although each interregional agenda reflects different regional realities, there has been convergence around seven issues: terrorism, transnational crime, drug trafficking, natural disasters, climate change, human trafficking, and illicit arms production and trafficking. However, convergence may not reflect a high level of political commitment towards a common global security agenda. Regarding the security lexicon used in these multilateral forums, it could be said that certain concepts do not travel easily between regions, as the concepts of 'non-traditional security' and 'citizen security' demonstrate.

In the following lines there is a brief analysis of how certain challenges have evolved in these interregional security agendas. Given the limited space, broader explanations as to why these matters have changed in certain ways cannot be offered. Nevertheless, some initial thoughts are presented on natural disasters and illegal exploitation of natural resources.

East Asia and LAC are regions highly vulnerable to natural disasters; consequently, they have given particular emphasis to these matters in their cooperation efforts. The FEALAC and the EU-LAC/CELAC agendas have included natural disasters from the beginning. In the ASEAN-EU agenda, however, these matters were included in 2007, after which they were mentioned in 2010, 2012, 2014 and 2017. In the ASEAN-EU agenda, the relatively late incorporation of these matters could be related to the specific path followed by EU member states, given their awareness of the impact of natural disasters on them. In 2009, the European Council agreed to increase cooperation for natural and man-made disaster prevention; in 2013 a Union Civil Protection Mechanism 
(UCPM) was created to protect the EU's peoples, environment and property from environmental disasters, marine pollution and acute health emergencies, "occurring inside or outside" the Union (EU 2013). Furthermore, in 2017 the EU agreed to increase its ability to cope with more complex and frequent natural disasters which have seriously affected several European countries, creating a scenario that has been described by the European Commission as the "new normal" (European Commission 2017).

The illegal exploitation of natural resources, "funds criminal and terrorist groups, facilitates money laundering and corruption, forcibly displaces local populations, speeds environmental destruction and creates situations of labour exploitation, labour trafficking, and sex trafficking" (Global Initiative 2016, vi). These matters were introduced in the three interregional agendas after the 2010s, though with different emphasis. The ASEAN-EU dialogue has included illegal fishing, trafficking in forest products and wildlife crimes. In the EU-LAC/CELAC agenda the presence of these matters has been quite irregular: trafficking in forest products was only mentioned in 2008, illegal trade in mining products was introduced for the first time in 2018 (EU-CELAC 2018), and illegal fishing or wildlife crimes have not been included at all. In the FEALAC agenda, only illegal fishing has been mentioned. These diverse paths could be related to different views on how to protect, and who should guard, natural resources; or to a perspective in which the internationalization of natural resources protection may have negative implications for state's sovereignty over its resources. For example, LAC governments have been especially active defending states' sovereign rights on natural resources (CELAC 2014; EU-CELAC 2103a; 2013b; China-CELAC 2015).

\section{Conclusions}

By analyzing and categorizing the content of key documents from the ASEAN-EU, EU-LAC/EU-CELAC and FEALAC dialogues, a set of interconnected matters were explored in this article. Regarding the assessment these forums have made of the regional and international security environment, they seem to share the view that increasing global interdependencies have created uneven benefits and common, complex challenges. Besides considering traditional security threats, these dialogues have progressively warned against the emergence of novel transnational and multidimensional security issues, such as: the impact of climate change, the rise of powerful non-state actors, the expansion of global criminal markets, and the increasing global consequences of health issues. An important discursive change took place during the 2010s, as transnational challenges were said to be threatening not only peoples and states, but also the global multilateral framework.

In regard to the role these interregional dialogues assign multilateral cooperation in confronting regional and global challenges, they share the view that it is only through effective multilateral responses that the international community will be able to cope with them. This is quite relevant 
in the current moment of the international society, when key state actors are turning their backs on multilateralism, and promoting unilateralism and exacerbated nationalism. Regarding the evolution of these bi-regional security agendas, it can be noticed that states have increasingly broken down threats and challenges to try to define and confront them more efficiently. These agendas have had different trajectories in the last two decades, the clearest features being: the progressive and rapid expansion of the ASEAN-EU agenda, the relatively constant number of issues in the EU-LAC/EU-CELAC agenda, and the irregular broadening and limiting path of the FEALAC agenda.

Considering the results of this preliminary empirical analysis on the ASEAN-EU, the EU-CELAC and the FEALAC interregional dialogue forums, and drawing on insights from interregionalism studies and security governance, more research needs to be done in at least three areas: (1) further exploration of the links between regionalism and interregionalism with global governance, and identification of what types of functions interregional dialogue forums perform towards an emerging global security governance architecture; (2) analysis of how security governance norms and practices are diffused, transmitted, contested or localized (Wiener 2014; 2018; Acharya 2018) in interregional dialogues, taking into account the role of different stakeholders; and (3) identification of how different interregional governance mechanisms and practices emerge to manage both traditional and non-traditional security threats and challenges, in 'North-South,' 'South-North' and 'South-South' interregional interactions.

This article is a modest contribution to the empirical analysis of interregionalism's role as a stepping-stone to advance security cooperation, and to how multilateral security governance can be used to generate different research paths regarding interregional security agendas. In order to acquire more insight on the changing interests, identities, norms and practices which shape interregional security cooperation, further empirical and theoretically-oriented research is needed.

\section{Acknowledgements}

This article is part of the 'EU-NormCon research project' ('Normative contestation in Europe: Implications for the EU in a changing global order') funded by the National R+D Plan of the Spanish Ministry of Economy and Competitiveness (CSO2016-79205-P).

\section{References}

Abad, G. "Non-triadic interregionalism: the case of FEALAC." In Asia and Latin America: political, economic and multilateral relations, edited by J. Dosch, and O. Jacob, 206-217. London: Routledge, 2010. 
Acharya, A. Constructing Global Order: agency and change in world politics. Cambridge: Cambridge University Press, 2018.

Allison, L. The EU, ASEAN and interregionalism: regionalism support and norm diffusion between the EU and ASEAN. Dordrecht: Springer, 2015.

Association of Southeast Asian Nations - ASEAN. Home. Jakarta, (s. a.). https://asean.org/ category/asean-statement-communiques/

Association of Southeast Asian Nations-European Union relations - ASEAN-EU. Twelfth ASEAN-EU Ministerial Meeting. Singapore, February 13-14, 1997.

Association of Southeast Asian Nations-European Union relations - ASEAN-EU. Joint

Declaration on Co-operation to Combat Terrorism. Presented at the 14 th ASEAN-EU Ministerial Meeting, Brussels, January 28, 2003 a.

Association of Southeast Asian Nations-European Union relations - ASEAN-EU. Joint Co-Chairmen's Statement. Presented at the 14th EU-ASEAN Ministerial Meeting, Brussels, January 27-28, 2003b.

Association of Southeast Asian Nations-European Union relations - ASEAN-EU. Joint Co-Chairmen's Statement. Presented at the 15th ASEAN-EU Ministerial Meeting, Jakarta, March 10, 2005.

Association of Southeast Asian Nations-European Union relations - ASEAN-EU. Nuremberg Declaration on an EU-ASEAN Enhanced Partnership. Nuremberg, March 15, 2007a.

Association of Southeast Asian Nations-European Union relations - ASEAN-EU. Joint Declaration. Presented at the ASEAN-EU Commemorative Summit, Singapore, November 22, 2007b.

Association of Southeast Asian Nations-European Union relations - ASEAN-EU. Plan of Action to Implement the Nuremberg Declaration on an EU-ASEAN Enhanced Partnership. Singapore, November 22, 2007c.

Association of Southeast Asian Nations-European Union relations - ASEAN-EU.

Co-Chair's Statement. Presented at the 18th ASEAN-EU Ministerial Meeting, Madrid, May 26, 2010.

Association of Southeast Asian Nations-European Union relations - ASEAN-EU. Co-Chairs' Statement. Presented at the 19th ASEAN-EU Ministerial Meeting, Brunei Darussalam, April 26-27, 2012a.

Association of Southeast Asian Nations-European Union relations - ASEAN-EU.

Bandar Seri Begawan Plan of Action to Strengthen the ASEAN-EU Enhanced Partnership. Presented at the 19th ASEAN-EU Ministerial Meeting, Brunei Darussalam, April 27, 2012 b.

Association of Southeast Asian Nations-European Union relations - ASEAN-EU.

Co-Chairs' Statement. Presented at the 20th EU-ASEAN Ministerial Meeting, Brussels, July 23, 2014. 
Association of Southeast Asian Nations-European Union relations - ASEAN-EU. Bangkok Declaration on Promoting an ASEAN-EU Global Partnership for Shared Strategic Goals. Presented at the 21st ASEAN-EU Ministerial Meeting, Bangkok, October 13-14, 2016. Association of Southeast Asian Nations-European Union relations - ASEAN-EU. Joint Statement on the 40th Anniversary of the Establishment of ASEAN-EU Dialogue Relations. Manila, August 6, 2017a.

Association of Southeast Asian Nations-European Union relations - ASEAN-EU. Plan of Action 2018-2022. Manila, August 6, 2017b.

Ayuso, A. "La Asociación UE-CELAC y la revisión del concepto de interregionalismomultinivel.” Revista Comentario Internacional, no. 15 (2015): 177-207. Ayuso, A., and S. Gratius. "América Latina y Europa: ¿̨repetir o reinventar un ciclo?" Pensamiento Propio, no. 44 (2016): 249-295.

Baert, F., T. Scaramagli, and F. Soderbaum, eds. Intersecting interregionalism: Regions, Global Governance and the EU. Dordrecht: Springer, 2014.

Betts, A. "The global governance of migration and the role of trans-regionalism." In Multilayered Migration Governance, edited by R. Kunz, S. Lavenex, and M. Panizzon, 32-42. Abingdon: Routledge, 2011.

Börzel, T., and T. Risse, eds. The Oxford Handbook of Comparative Regionalism. Oxford: Oxford University Press, 2016.

Breslin S., and S. Croft, eds. Comparative regional security governance. London: Routledge, 2013. Britz, M., and H. Ojanen. "Multilateral security governance." In European Security

Governance: The European Union in a Westphalian World, edited by C. Wagnsson, J. Sperling, J. Hallenberg, 19-39. London: Routledge, 2009.

Bryman, A. Social research methods. 4th ed. Oxford: Oxford University Press, 2012. Caballero-Anthony, M., ed. An introduction to non-traditional security studies: a transnational approach. Los Angeles: Sage, 2016.

Ceccorulli, M., and S. Lucarelli. "Introduction 1: conceptualizing multilateral security governance." In The EU and multilateral security governance, edited by S. Lucarelli, L. Van Langenhove, J. Wouters, 11-25. New York: Routledge, 2013.

Christou, G., S. Croft, M. Ceccorulli, and S. Lucarelli. "European Union security governance: putting the 'security'back in." European Security 19, no. 3 (2010), 341-359. doi: https://doi.org/10.1080/09662839.2010.526109

Comisión Económica para América Latina y el Caribe - CEPAL. Fortalecimiento de la cooperaciónbirregional entre América Latina y Asia y el Pacifico: El papel del FOCALAE. Santiago: Observatorio América Latina-Asia Pacífico/CEPAL, 2013.

Community of Latin American and Caribbean States-China relations - China-CELAC. China-Latin American And Caribbean Countries Cooperation Plan (2015-2019). Presented at the First Ministerial Meeting China-CELAC Forum. Beijing, January 8-9, 2015. 
Community of Latin American and Caribbean States - CELAC. Havana Declaration II CELAC Summit. La Habana, January 28-29, 2014.

Doidge, M. "Interregionalism and the European Union: conceptualising group-to-group relations." In Intersecting Interregionalism, edited by F. Baert, T. Scaramagli, and F. Soderbaum, 37-54. Dordrecht: Springer, 2014.

Domínguez, R. EU Foreign Policy towards Latin America. London: Palgrave Macmillan, 2015. Engel, U., H. Zinecker, F. Mattheis, A. Dietze, and T. Plötze, eds. The New Politics of Regionalism: Perspectives from Africa, Latin America and Asia-Pacific. New York: Routledge, 2016.

Elo, S., M. Kääriäinen, O. Kanste, T. Pölkki, K. Utriainen, and H. Kyngäs. "Qualitative content analysis: a focus on trustworthiness." Sage Open 4, no. 1 (2014), 1-10 . doi: https://doi.org/10.1177/2158244014522633

European Commission. RescEU: a new European system to tackle natural disasters. Brussels, 23 November 2017.

European Union. "Decision No 1313/2013/EU on a Union Civil Protection Mechanism." Official Journal of the EU, December 20, 2013.

European Union. European External Action Service. Brussels, 2016. https://eeas.europa.eu/ headquarters/headquarters-homepage_en

European Union - Community of Latin American and Caribbean States relations EU-CELAC. Santiago declaration. Presented at the First EU-CELAC Summit, Santiago de Chile, January 27, 2013a. http://www.europarl.europa.eu/cmsdata/124264/ ST_5747_2013_INIT_EN.pdf

European Union - Community of Latin American and Caribbean States relations - EU-CELAC. Action Plan 2013-2015. Presented at the First EU-CELAC Summit, Santiago de Chile, January 27, 2013b. http://www.europarl.europa.eu/ cmsdata/124263/2013_santiago_summit_eu-celac_action_plan_en.pdf

European Union - Community of Latin American and Caribbean States relations EU-CELAC. Shaping our common future: working together for prosperous, cohesive and sustainable societies for our citizens: Brussels Declaration. Presented at the $2 \mathrm{nd}$ EU-CELAC Summit, Brussels, June 11, 2015.

European Union - Community of Latin American and Caribbean States relations EU-CELAC. Santo Domingo Declaration. Presented at the EU-CELAC Ministerial Meeting, Santo Domingo, October 26, 2016 a.

European Union - Community of Latin American and Caribbean States relations EU-CELAC. Assessment of Programmes and Actions. Presented at the EU-CELAC Ministerial Meeting, Santo Domingo, October 26, 2016 b.

European Union - Community of Latin American and Caribbean States relations - EU-CELAC. Building bridges and strengthening our partnership to face global challenges. Declaration following the 2nd EU-CELAC Foreign Ministers meeting, Brussels, 16-17 October 2018. 
European Union - Latin America and the Caribbean Foundation - EU-LAC. Digital Library of the EU-LAC Foundation. Hamburg, 1999a. https://eulacfoundation.org/en/digital-library European Union - Latin America and Caribbean Foundation - EU-LAC. Declaration of Rio de Janeiro. Presented at the First Summit. Latin America and Caribbean-EU, Rio de Janeiro, June 29, 1999 b.

European Union - Latin America and Caribbean Foundation - EU-LAC. Political Declaration: The Madrid Commitment. Presented at the EU-LAC Summit, Madrid, May 17, 2002.

European Union - Latin America and Caribbean Foundation - EU-LAC. Declaration of Guadalajara. Presented at the 3rd Latin America and Caribbean-EU Summit, Guadalajara, May 28-29, 2004.

European Union - Latin America and Caribbean Foundation - EU-LAC. Declaration of Vienna: Strengthening the Bi-Regional Strategic Association. Presented at the 4 th EU-LAC Summit, Vienna, May 12, 2006.

European Union - Latin America and Caribbean Foundation - EU-LAC. Lima Declaration: Addressing Our Peoples' Priorities Together. Presented at the 5th Latin America and Caribbean-EU Summit, Lima, May 16, 2008.

European Union - Latin America and Caribbean Foundation - EU-LAC. Madrid Declaration: Towards a new stage in the bi-regional partnership. Madrid Action Plan 2010-2012. Presented at the 6th EU-LAC Summit, Madrid, May 18, 2010.

Forum for East Asia-Latin America Cooperation - FEALAC. Index. Seoul, (s. a.). http://www.fealac.org/new/index.do

Forum of East Asia-Latin America Cooperation - FEALAC. Manila Plan of Action to Further Enhance Cooperation between East Asia and Latin America. Presented at the 2nd FEALAC Foreign Ministers' Meeting. Manilla, January 30-31, 2004.

Forum of East Asia-Latin America Cooperation - FEALAC. Ministerial Declaration and Programme of Action. Presented at the 3rd Foreign Ministers' Meeting, Brasilia August 22-23, 2007.

Forum of East Asia-Latin America Cooperation - FEALAC. Tokyo Declaration. Presented at the 4th FEALAC Foreign Ministers Meeting. Tokyo, January 17, 2010.

Forum of East Asia-Latin America Cooperation - FEALAC. Buenos Aires Declaration. Presented at the 5th FEALAC Foreign Ministers Meeting, Buenos Aires, August 24-25, 2011.

Forum of East Asia-Latin America Cooperation - FEALAC. Uluwatu Declaration. Presented at the 6th FEALAC Foreign Ministers Meeting, Bali, June 13-14, 2013.

Forum of East Asia-Latin America Cooperation - FEALAC. Declaration of San Jose. Presented at the 7th FEALAC Foreign Ministers Meeting, San Jose, August 21, 2015. Forum of East Asia-Latin America Cooperation - FEALAC. Busan Declaration: One Vision, New Action. Presented at the 8th Foreign Ministers' Meeting, Busan, August 31, 2017. 
Global Initiative. Organized Crime and Illegally Mined Gold in Latin America. Presented at the Global Initiative against Transnational Organized Crime, Geneva, April 2016.

Hameiri, S., and L. Jones. "The politics and governance of non-traditional security." International Studies Quarterly 57, no. 3 (2013), 462-473. doi: https://doi.org/10.1111/isqu.12014

Hänggi, H. "Interregionalism as a multifaceted phenomenon: In search of a typology.” In Interregionalism and international relations, edited by J. Rüland, H. Hänggi, and R. Roloff, 51-82. London: Routledge, 2006.

Heine, J., and R. Thakur, eds. The dark side of globalization. New York: UN University Press, 2011.

Inter-American Commission on Human Rights - IACHR. Report on Citizen Security and Human Rights. Washington DC, December 31, 2009.

Kacowicz, A., and G. Press-Barnathan. "Regional Security Governance." In The Oxford Handbook of Comparative Regionalism, edited by T. Börzel, and T. Risse, 297-322. Oxford: Oxford University Press, 2016.

Kirchner, E. J., and J. Sperling, eds. Global security governance: Competing perceptions of security in the twenty-first century. London: Routledge, 2007.

Koschut, S. "Overlapping Interregionalism, Identities, and Transatlantic Security Governance." In Interregionalism and the Americas, edited by G. L. Gardini, S. Koschut, and A. Falke, 91-108. Lanham: Lexington Books, 2018.

Krahmann, E. "Security governance and networks: New theoretical perspectives in transatlantic security." Cambridge Review of International Affairs 18 , no. 1 (2005), 15-30.

Low, L. "The Forum for East Asia-Latin America Cooperation (FEALAC): Embryonic interregionalism." In Interregionalism and international relations, edited by J. Rüland, H. Hänggi, and R. Roloff, 105-116. London: Routledge, 2006.

Lucarelli, S., L. Van Langenhove, and J. Wouters, eds. The EU and Multilateral Security Governance. London: Routledge, 2013.

Malamud, A., and P. Seabra. "Challenging the Political and Security Dimensions of the EU-LAC Relationship." In Interregionalism and the European Union: A Post-Revisionist Approach to Europe's Place in a Changing World, edited by M. Telò, L. Fawcett, and F. Ponjaert, 325-336. London: Routledge, 2015.

Organisation for Economic Co-operation and Development - OECD. "Illicit Trade: Converging Criminal Networks.” In OECD Reviews of Risk Management Policies, edited by Organisation for Economic Co-operation and Development - OECD. Paris, 2016. Rees, N. "EU and ASEAN: Issues of regional security." International Politics 47, no. 3-4 (2010), 402-418. doi: https://doi.org/10.1057/ip.2010.16

Reiterer, M. "Interregionalism as a new diplomatic tool: The EU and East Asia." European Foreign Affairs Review 11, no. 2 (2006), 223-243. 
Rubiolo, M. "South America and Southeast Asia interregional relations:

Beyond South-South Bilateralism.” Meridiano 47 19, (2018), e19013.

doi: https://doi.org/10.20889/M47e19013

Rüland, J., H. Hänggi, and R. Roloff, eds. Interregionalism and International Relations: A Stepping Stone to Global Governance? London: Routledge, 2006.

Rüland, J. "Interregionalism and International Relations: Reanimating an Obsolescent Research Agenda?" In Intersecting interregionalism: Regions, Global Governance and the EU, edited by F. Baert, T. Scaramagli, and F. Soderbaum, 15-35. Dordrecht: Springer, 2014.

Ruzza, S., A. P. Jakobi, and C. Geisler, eds. Non-state Challenges in a Re-ordered World: The Jackals of Westphalia. London: Routledge, 2015.

Sanahuja, J. A. La UE y CELAC: Revitalización de una relaciónestratégica. Hamburg: EU-LAC Foundation, 2015.

Santini, R., S. Lucarelli, and M. Pinfari "Interregionalism: a security studies perspective." In Intersecting interregionalism: Regions, Global Governance and the EU, edited by F. Baert, T. Scaramagli, and F. Soderbaum, 171-88. Dordrecht: Springer, 2014.

Selleslaghs, J. “The EU's performance in Latin America's fight against drugs and related organized crime." Global Affairs 2, no. 5 (2016), 527-537. doi: https://doi.org/10.1080/23340460.2016.1276403

Song, W. "Regionalisation, inter-regional cooperation and global governance." Asia Europe Journal 5, no. 1 (2007), 67-82. doi: https://doi.org/10.1007/s10308-006-0094-y

Sperling, J. "Introduction: security governance in a Westphalian world". In European security governance: the European Union in a Westphalian world, edited by C. Wagnsson, James Sperling, J. Hallenberg. London: Routledge, 2009.

Stambøl, E. "EU initiatives along the 'cocaine routes' to Europe: Fighting drug trafficking and terrorism by proxy?" Small Wars \& Insurgencies 27, no. 2 (2016a), 302-324. doi: https://doi.org/10.1080/09592318.2016.1151534

Stambøl, E. "Governing cocaine supply and organized crime from Latin America and the Caribbean: The changing security logics in European Union external policy." European Journal on Criminal Policy and Research 22, no. 1 (2016b), 1-18. doi: https://doi.org/10.1007/s10610-015-9283-9

Storz, C., and J. Rüland. "Interregionalism and interregional cooperation: The case of Asia-Europe relations." In Asian-European Relations: Building Blocks for Global Governance? edited by J. Ruland, G. Schubert, and C. Storz, 3-31. London: Routledge, 2008.

Tsardanidis, C. "Inter-regionalism: a comparative analysis of ASEM and FEALAC." In Asia and Latin America: political, economic and multilateral relations, edited by J. Dosch, and O. Jacob, 218-236. London: Routledge, 2010. 
United Nations Security Council - UNSC. Maintenance of international peace and security: addressing complex contemporary challenges to international peace and security (S/PV.8144). Apresented at the 8144th United Nations Security Council Meeting. New York, December 20, 2017.

Wiener, A. A theory of contestation. Berlin: Springer, 2014.

Wiener, A. Constitution and Contestation in Global Governance. Cambridge: Cambridge University Press, 2018. 